\title{
BEVARANDEFRÅGOR - EN ANGELÄGENHET FÖR OSS ALLA!
}

\author{
Jan-Erik Bergh \& Monika Akerlund
}

Att bevara föremål - och med föremål avses här även dokument, böcker osv. - att hålla dem i oskadat skick, är en av de allra viktigaste uppgifterna for alla, som arbetar i museer, arkiv och liknande institutioner. Enligt ICOM:s stadgar och yrkesetiska regler definieras detta som "forebyggande konservering».

Vilka faror lurar då på föremålen och varför existerar riskerna överhuvudtaget? Ytterst kan vi förklara mycket med hjälp av termodynamikens lagar, som säger att entropin i universum ökar. Detta får till följd att alla system går från ordning mot oordning, om man inte tillför energi för att upprätthålla eller återskapa ordningen.

För föremålen innebär det, att exempelvis en nyckel av järn - som ju blivit en nyckel tack vare den energi, som tillförts järnmalmen - om den lämnas åt naturens krafter återgår till oxidstadiet, dvs. i princip till malm. Detta sker genom kemiska reaktioner, men även fysikaliska faktorer är av betydelse vid nedbrytningen av föremål. Sålunda verkar ljus, framför allt av kort våglängd, nedbrytande på papper, textilier, färger $\mathrm{mm}$.

Också biologiska faktorer är viktiga i sammanhanget. Det kan vara fråga om bakterie- eller mögelsvampangrepp eller om skador tillfogade av insekter, gnagare etc.
I den statliga utredningen, Minne och bildning (1994), indelas museernas verksamhet $\mathrm{i}$ tre huvudområden: samla in och dokumentera - vårda och bevara - visa, undervisa och förmedla (s. 83-84). Därtill kommer även uppgiften att forska, som en integrerad del av verksamheten (s. 84-85). Grunden för ett museums arbete är de insamlade föremålen och övrig dokumentation. Målet för hela verksamheten är bildning. Bevarandefrågorna, den förebyggande konserveringen, kan tyckas ha en inklämd ställning däremellan eller kan ses som marginella $i$ förhållande till de stora uppdragen att samla och att förmedla kunskap.

Men - uppdraget att bevara museiföremålen har ingen bestämd tidshorisont, utan ett evighetsperspektiv. Detta ger dessa frågor en central ställning. Om föremålen förstörs, innan de hinner ställas ut eller ge forskarna nödvändig information, kommer heller aldrig bildningsmålet inom räckhåll. 
JAN-ERIK BERGH \& MONIKA $\AA$ KERLUND

\section{SESAM OCH VARDBERGET}

SESAM-projektet tillkom som en räddningsaktion för att bl a åtgärda museernas vårdberg eller isberg, som det beskrevs i utredningen (s. 92). Till museerna anknöts under ett par år en stor skara unga välutbildade människor, angelägna att få lära sig museimannaskapets uppgifter och göra en insats. De flesta fick genomgå en fem veckors kurs med en kunskapsgrund, som alla museianställda borde få. De har arbetat oförtrutet, och visst har de gjort en fantastisk insats. Snart är dock deras tillmätta arbetstid slut. Har vi då lyckats smälta isberget eller har vi snarare endast fătt ett klarare begrepp om vad som finns under vattenlinjen? Helt klart återstår oerhört mycket arbete. Även om det stora ackumulerade vårdbehovet undanröjts, måste föremålsvården fortsätta. Den är en nödvändig och kontinuerlig uppgift. Om arbetet inte utförs, kommer valet av de föremål som bevaras till eftervärlden inte längre att vara vårt. Med den ovannämnda museiutredningens ord: Mal och råttor ska inte bestämma vad vi minns! (s. 97).

Det är en i högsta grad viktig appell!

\section{DE SVENSKA MUSEERNAS SKADEDJURSGRUPP}

PRE-MAL, (Pest Research and Education Museums, Archives and Libraries), de svenska museernas, arkivens och bibliotekens skadedjursgrupp, arbetar sedan tio år med den del av förebyggande konservering, som har med skadedjursangrepp att göra. Gruppen leds från Naturhistoriska riksmuseet. Ordförande är museichefen Désirée Edmar. Expertkunskaper i textil-, djur-, trä- och papperskonservering, i entomologi samt yrkesmedicin är representerade.

Arbetet har finansierats av Arbetsmiljöfonden, Statens kulturråd genom anslag ur ansvarsmuseernas forskningsmedel samt Kulturdepartementet genom SESAM.

Att bekämpa skadedjur i museisamlingar är en komplicerad uppgift. Åtgärderna måste vara effektiva mot skadedjuren utan att föremålen skadas eller personalen utsätts för hälsorisker. Forskningen inriktas därför på dessa tre frågeställningar.

\section{Forskning}

Eftersom det är olämpligt att spruta kemiska medel på museiföremål testas istället insekticidbehandling av olika förpackningsmaterial och medlens förmåga att vandra över till föremålen. Det görs i samarbete med Statens Skadedyrlaboratorium i Danmark.

Ett intressant alternativ är behandling med låg syrehalt. Försök med vakuum och användning av kvävgas som bekämpningsmetoder utförs på olika skadedjursarter, i samarbete med Statens Skadedyrlaboratorium och Danmarks Tekniske Universitet. (Bergh et al 1996)

$\mathrm{Nu}$ har gruppen fătt EU-medel för att medverka i projektet Save Art, som ska utvärdera en metod, där man behandlar skadedjursangripna föremål med låg syrehalt med hjälp av en syreavskiljande apparatur. Projektet är ett samarbete med institutioner i Italien, Storbritannien och Spanien.

Frysning är numera ett allt vanligare sätt att behandla skadedjursangripna föremål. Det finns inte många undersökningar gjorda, om vilka risker denna behandling 
innebär för föremålen. Därför görs försök med frysning av nya och gamla ullfibrer i samarbete med Institutet för Fiber- och Polymerteknologi. Frysförsök har även på PRE-MALs uppdrag utförts på olika papperskvaliteter av Sveriges Provnings- och Forskningsinstitut. (Sidenbladh et al 1993, Antonsson och Samuelsson 1996)

Rester av gamla bekämpningsmedel i museisamlingar kan vara en oroskälla för personalen. Denna oro ledde till att en undersökning av bekämpningsmedelsexponering hos museipersonal utfördes av PRE-MALs yrkesmedicinska experter tillsammans med Statens Lantbrukskemiska Laboratorium. (Kolmodin-Hedman et al 1993)

Skadedjursproblemet är aktuellt i hela världen och forskning på området sker i flera länder. Exempel på arbeten är Becker (1982), Druzik (1994), Child (1989), Hanlon et al (1992), Pinniger (1991), Valentin (1993), Zaitseva (1993). ICOM, Committee of Conservation, för naturligtvis fram dessa frågor vid sina konferenser. (Exempelvis vid mötet $\mathrm{i}$ Edinburgh 1996) Man kan ändå t.ex. se i Conservation $O n$ Line på Internet och i dess diskussionslista Cons DistList, att det finns ett omättligt behov av information på området.

\section{Kunskapsspridning}

För att föra ut kunskapen anordnar Naturhistoriska riksmuseet kurser för museipersonal. PRE-MALs medlemmar håller föredrag vid konferenser och i andra sammanhang. Museerna har också möjlighet att få hjälp med artbestämning av skadeinsekter, och få råd om åtgärder.

Monika Åkerlunds bok Ängrar - finns dom...? Om skadeinsekter $i$ museer och magasin gavs ut av Svenska museiförening- en 1991. Videofilmen med samma namn premiärvisades i maj 1993.

I år utkommer boken Från silverfisk till hälsorisk. Skadedjur och åtgärder $i$ samlingar av Monika Åkerlund, Sylwia Flato och Anna Hellekant.

Symposier anordnades 1984 och 1993. (Nordenstam och Stenmark 1984, Stenmark och Akerlund 1993) Gruppen inbjuder nu till The 3rd Nordic Symposium on Insect Pest Control in Museums, 24-25 september 1998, i Naturhistoriska riksmuseet i Stockholm. Ett 20-tal föredragshållare medverkar, de flesta från de nordiska länderna, men även flera forskare från andra länder. Särskilt inbjudna utomnordiska föreläsare är David Pinniger, forskare och skadedjurskonsult och Adrian Meyer, gnagarexpert, båda från Storbritannien samt Tom Strang, forskare och konservator från Canadian Conservation Institute, CCI. De är internationellt ledande experter inom området. Den som är intresserad att deltaga i symposiet kan kontakta Monika Åkerlund.

\section{DEN FÖREBYGGANDE KONSERVE- RINGENS FRAMTIDA STÄLLNING}

Som tidigare nämnts är vårdproblemen inte något som kan klaras av en gång för alla utan kräver ett ständigt ihärdigt arbete. Arbetet måste ha två huvudinriktningar - akutinsatserna och den forrebyggande bälsovården. Hela tiden tillför dessutom forskningen och utvecklingsarbetet ny kunskap, som måste utvärderas och spridas. Det är angeläget, att ett bevarandetänkande genomsyrar alla nivåer inom museerna och deras styrelser. Givetvis måste personer med beslutsansvar vara medvetna om grundläggande strategier, 
JAN-ERIK BERGH \& MONIKA ÁKERUND

36 men om inte all personal, som arbetar inom en institutions väggar, har kunskap om förebyggande konservering, kommer alla strategier att mer eller mindre misslyckas. Inom skadedjurssektorn är detta en del av vad som kallas IPM - Integrated Pest Management. Flera av dessa frågor hanteras av enskilda konservatorer och konservatorssammanslutningar, men vissa övergripande frågor saknar naturlig hemvist $\mathrm{i}$ de traditionella nätverken inom museivärlden. I dessa fall ser vi det som väsentligt, att tvärvetenskapliga grupper som PRE-MAL ges ekonomisk möjlighet att verka.

PRE-MALs arbete ska vara en hjälp för museerna, arkiven och andra liknande institutioner $\mathrm{i}$ arbetet med vård och bevarande av samlingar. Emellertid får man inte glömma, att en huvudorsak till att vårdberget vuxit sig så stort är, att alltför få konservatorer har alltför mycket att göra. Detta framgår med all önskvärd tydlighet i museiutredningens bilagedel, såväl i de avsnitt, som behandlar situationen vid museerna som i den slutsats, som dras: Efter att forremålen kategoriindelats och prioriterats, maste museerna ha ordinarie foremålsvårdsverksambet av en sådan omfattning att inte ny eftersläpning uppstår. (s. 235).

En satsning inom hela bevarandesektorn är en investering, som betalar sig mångdubbelt i framtiden! Att bevara föremålen från nedbrytning är en förutsättning för att berörda institutioner ska kunna genomföra sitt uppdrag och därmed ge kommande generationer möjlighet att få njuta av en rik kulturskatt.

\section{TACK}

Författarna tackar Martin Andrén, Désirée Edmar, Monika Fjaestad och Staffan Thorman för värdefulla synpunkter på manuskriptet.

\section{REFERENSER}

Antonsson, M. \& Samuelsson M.L. 1996. Effects of Repeated Freezing on Paper Strength. Swedish National Testing and Research Institute, Materials Technology, SP Report 1996:19.

Becker, P.C. och Brockman, W. 1982 Library Pests. Pest control 50 (12): 43.

Bergh, J-E.; Mourier, H. and Poulsen, K.P. 1996 Lethal Effects of Low Pressure (Vacuum) on some Museum Pest Insects. 11th Triennal Meeting Edinburgh 1-6 September 1996: 3-7.

Child, R.E. 1989 Fumigation in museums: a possible alternative. Museum Journal 88 (4).

Druzik, J.R. (ed) 1994. Research Abstract of the Scientific Program. GCI Scientific Program Report, December 1994.

Hanlon, G., Daniel, V., Ravenel, N. och Maekawa, S. 1992 Dynamic System for Nitrogen Anoxia of Large Museum Objects: A Pest Eradication Case Study. 2nd International Conference on Biodeterioration of Cultural Property, Oct 5-8, 1992, Yokohama, Japan.

ICOM:s stadgar och etiska regler. Svenska museiföreningen. (Översättning 1989 A.-L. Kemdal).

ICOM CC 11th Triennial Meeting Edinburgh 1-6 September 1996, Preprints Vol 1.

Kolmodin-Hedman, B.; Flato. S.; Åkerblom, M. 1993 Irritative symptoms in museum personnel a complex environmental exposure. Proceedings of Indoor Air 1.

Kulturdepartementet 1994 Minne och bildning. Museernas uppdrag och organisation + bilagedel, SOU 1994:51.

Nordenstam, B.; Stenmark, A. (Ed) 1984 
Naturhistoriskt museisymposium, 12 nov 1984, Skadeinsekter i museisamlingar och Nordisk museisamverkan. Naturhistoriska riksmuseet, Stockholm.

Pinniger, D.B. 1991 New developments in detection and control of insects which damage museum collections. Biodeterioration abstracts 5 (2): 126-130.

Sidenbladh, R, Stenmark, A. och Wallenborg, I. 1993. Erfarenheter av försök över frysningens inverkan på museala ullfibrer. Nordiskt symposium om bekämpning av skadedjur i museer, Stockholm 12-14 maj 1993 Naturhistoriska riksmuseet, Stockholm: 100-118.

Stenmark, A. och Åkerlund, M (ed).1993 Nordiskt symposium om bekämpning av skadedjur $i$ museer, Stockholm 12-14 maj 1993 Naturhistoriska riksmuseet, Stockholm.

Valentin, N. 1993. Comparative Analysis of Insect Control by Nitrogen, Argon and Carbon dioxide in Museum, Archive and Herbarium Collections. International Biodeterioration and Biodegradation 32: 263-278.

Zaitseva, G.A. 1993. Studies on Insects Injurious to Museum Collections and their Control in the USSR. Recent Advances in Biodeterioration and Biodegradation. Vol. I: 233-257.

Åkerlund, M. 1991: Ängrar-finns dom...? Om skadeinsekter i museer och magasin. Svenska museiföreningen, Uppsala.

Åkerlund, M., Flato,S. och Hellekant, A. 1998: Frä silverfisk till hälsorisk. Skadedjur och åtgärder $i$ samlingar. LT:s förlag, Arlöv.

\section{SUMMARY}

Conservation - a concern for all of us

The laws of thermodynamics tell us that the entropy in a closed system increases, which means that systems go from order to disorder, thus explaining e. g. that a key manufactured from ore will turn into ore again if no energy is invested in maintai- ning it as a key. Objects can be degraded not only by chemical or physical processes, but also by biodeterioration. The later is processed by infestation from mould or bacteria or by insects, rodents etc.

The official governmental report "Minne och bildning» (Swedish Department of Culture 1994) discusses the main tasks of a museum: to collect and record - to take care of and preserve - to display and educate. Research programs are integrated parts of these activities. Preventive conservation is by the authors considered as a most important field of activity, as not only the result of display and education tasks but also much of the research is depending on well preserved objects.

A Swedish governmental project, SESAM, was started about two years ago as an effort to reduce the large amount of objects waiting for conservation - the mountain of untreated objects - but also as a help for the museums to open up their collections by e. g. transferring the records into digitalised form.

The working group of the Swedish museums, PRE-MAL (Pest Research and Education Museums, Archives and Libraries) has members who are specialised in textile, paper, wood and animal conservation, in entomology and in occupational health research. PRE-MAL has been active during about ten years with problems concerning control of museum pest insects and is now financed by SESAM.

The research program of the group is concentrated on the effectiveness of treatment with certain insecticides and low oxygen (vacuum and nitrogen) (in co-operation with the Danish Pest Infestation Laboratory and the Technical University of Denmark), the impact of freezing on wool fibres and paper, and problems related to staff exposed to insecticides (especially chlorated carbohydrates).

The education program includes courses, papers, conference lectures, species identification, advice, books and a video tape. We have arranged two Nordic symposia and will host a third one in 
Jan-Erik Bergh \& Monika ÁkerLund

38 Stockholm in September 1998. Special guest speakers on this occasion will be David Pinniger and Adrian Meyer, England and Tom Strang, Canada.

PRE-MAL's members look upon themselves as a support for museums, archives and libraries in questions concerning preventive conservation, especially pest insect problems. We find it important that this type of inter-disciplinary group will also in the future be given economical support. Together with an investment in good possibilities for the preventive conservation activity in the museums and other institutes, this will highly reduce costs in the future.

Monika Akerlund är biolog och arbetar på Naturhistoriska riksmuseet sedan 1980 Hon har en fil.kand.-examen med inriktning på entomologi. Sedan 1985 arbetar hon med skadedjursproblemet $i$ museer, där både forskning och undervisning ingair. Hon anordnar kurser och håller forredrag i ämnet. Hon är också forfattare till ett par böcker samt medproducent till en video om skadedjur och skadedjursbekämpning i samlingar. Monika Akerlund är sekreterare i PRE-MAL (Pest Research and Education-Museums, Archives and Libraries), de svenska museernas, arkivens och bibliotekens skadedjursgrupp.

Adr. Naturbistoriska riksmuseet, Regionala enheten, Box 50007, S-104 05 Stockholm e-post: monika.akerlund@nrm.se

Jan-Erik Bergh disputerade på en avhandling om insekters flygaktivitet $i$ samband med kallfrontpassager. Han har arbetat som lärare i biologi och kemi, som museianställd med frägor rörande museiklimat, skadeinsekter och korrosion och innehar nu en tjänst som universitetslektor i biologi vid Högskolan Dalarna. Han är forskningsansvarig inom PRE-MAL och undersöker insekters överlevnad i vakuum och kvävgasatmosfär.

Adr. Högskolan Dalarna, Kultur och Lärande,

S-791 88 Falun

e-post:jeb@du.se 